\title{
Combination Effect of The Extract of Avocado Leaf and Seed (Persea americana) on Level of Total Cholesterol, LDL, and HDL in Mice (Mus musculus) with Hypercholesterolemia
}

\author{
Muhammad Rafif Alfian Dita ${ }^{1}$, Indri Safitri Mukono², Maftuchah Rochmanti ${ }^{*}$ \\ ${ }^{1}$ Faculty of Medicine, Universitas Airlangga, Surabaya, Indonesia \\ ${ }^{2}$ Department of Biochemistry, Faculty of Medicine, Universitas Airlangga, Surabaya, Indonesia - Dr. Soetomo General \\ Hospital Surabaya, Indonesia \\ ${ }^{3}$ Department of Pharmacology, Faculty of Medicine, Universitas Airlangga, Surabaya, Indonesia - Dr. Soetomo General \\ Hospital Surabaya, Indonesia
}

\section{A R T I C L E I N F O}

\section{Article history:}

Received 24 June 2019

Received in revised form 26 June 2019

Accepted 29 June 2019

Available online 30 June 2019

\section{Keywords:}

Cholesterol,

Low Density Lipoprotein,

High Density,Lipoprotein Avocado, Persea americana.

*) Corresponding author: maftuchah-r@fk.unair.ac.id

\begin{abstract}
A B S T R A C T
Introduction: Traditional and herbal medicine are two of the primary treatments in a developing country. Both avocado leaf extract and avocado seed extract (Persea americana) have been proven to have an antihyperlipidemic effect in experimental animals. This study was conducted to analyze the effect of avocado leaf and seed extract in a combination form on total cholesterol, LDL, and HDL of hypercholesterolemia mice induced by high fat diet and duck egg yolk.

Methods: The sample unit of this study consisted of 25 mice (Mus musculus) and divided into 5 groups: KO1 (control), KO2 (hypercholesterolemia group), KO3 ( $1^{\text {st }}$ treatment group), KO4 (2 $2^{\text {nd }}$ treatment group), and $\mathrm{KO} 5$ ( $3^{\text {rd }}$ treatment group). The induction phase was done for 35 days, whilst the treatment phase was done for 28 days. All data were analyzed using $t$ test and one-way ANOVA. Results: Administration of the combination including avocado leaf and seed extract (CALSE) in all treatment group proved to decrease total cholesterol and LDL level in mice although it was not statistically significant $(\mathrm{p}=0,420 ; \mathrm{p}=0,882)$. Meanwhile, CALSE had a different effect on HDL $\mathrm{KO} 3$ level with HDL KO4 and KO5 level, in which HDL KO3 level tended to decrease and HDL $\mathrm{KO} 4$ and $\mathrm{KO} 5$ level tended to increase.

Conclusion: In conclusion, CALSE has the potential to act as an antihyperlipidemic agent which derive from flavonoid and saponin. The potential efficacy might be achieved in a combination rather than in an individual form.
\end{abstract}

\section{Introduction}

Traditional medicine and herbal are two of the primary treatment in developing countries 1 . Indonesia's citizens have used many plants as a source of medicine. Avocado (Persea americana) is one of many plants that's been used as a medicine.

Avocado is a plant that has wide pharmacological effects. $^{2}$ The wide effect is caused by its various phytochemical content, such as alkaloid, steroid, saponin, flavonoid, tannin, and fenol. ${ }^{3}$ One of its pharmacological effect from avocado is being an antihyperlipidemic agent. Some studies have proved that both avocado leaf extract and avocado seed extract have an antihyperlipidemic effect. Administration of avocado leaf extract with the doses of 20 $\mathrm{mg} / \mathrm{kgBW}$ and $40 \mathrm{mg} / \mathrm{kgBW}$ caused a significant decrease in total cholesterol, LDL, and cause a significant increase in HDL level of the rats. 4 Whilst administration of avocado seed extract with the doses of $125 \mathrm{mg} / \mathrm{kgBW}, 250 \mathrm{mg} /$ $\mathrm{kgBW}$, and $500 \mathrm{mg} / \mathrm{kgBW}$ caused a significant decrease in the total cholesterol and the LDL level of the mice. ${ }^{5}$

Antihyperlipidemic effect of avocado seed and leaf extract was thought to happen due to flavonoid and saponin content. Arukwe et al. 2012 reported that avocado leaf has the most flavonoid content while the avocado seed has the most saponin content. ${ }^{3}$ Flavonoid and saponin can act synergistically as antihyperlpidemic agents through its mechanism to increase insulin induced gene $1 / 2$ (INSIG1/2) activity. ${ }^{6}$ This gene caused degradation of sterol regulatory element-binding protein 1c (SREBP-1c) which is a protein that is responsible for the synthesis of HMGCoA reductase. The decrease in $\mathrm{HMG}-\mathrm{CoA}$ reductase level will lead to interference of cholesterol synthesis in 
the liver. Flavonoid and saponin individually also act as an antihyperlipidemic agent through its own mechanisms. The flavonoid as a main phytochemical in avocado leaf extract was known to act as an antihyperlipidemic agent through its interference on $\mathrm{HMG}-\mathrm{CoA}$ reductase enzyme ${ }^{7}$ and acetyl-CoA carboxylase enzyme. ${ }^{8}$ Whilst saponin, as a main phytochemical in avocado seed extract, was known to act as an antihyperlipidemic agent through its interference on lipase pancreas enzyme that leads to the disruption on lipid absorption. ${ }^{9}$

\section{Methods}

\section{Plant material and preparation of extract}

The leaves of avocado (Persea americana) were acquired from Unit Pelaksana Teknis Medika Batu, Malang. The leaves of avocado were dried under the sun for a week. After a week, the dry leaves of avocado were blended into a fine powder $(200 \mathrm{~g})$. The fine powder leaves of avocado are then extracted with $1000 \mathrm{~mL}$ of methanol $70 \%$ and continuously evaporated by evaporator for 1 hour. Leaf extract of avocado was diluted using distilled water and stored at $4^{\circ} \mathrm{C} .4$

The seeds of avocado were acquired from Unit Pelaksana Teknis Medika Batu, Malang. The seeds of avocado were cut into small parts and dried under the sun. Dried seeds of avocado were blended into a fine powder (200 g). Fine powder seed of avocado extracted with $1000 \mathrm{~mL}$ of methanol $75 \%$ using soxhlet extractor and continuously evaporated by evaporator for 1 hour. The seed extract of avocado was diluted using distilled water and stored at $4^{\circ} \mathrm{C} .^{5}$

\section{Experimental animal}

Twenty-five male, healthy, Mus musculus weighing about $20-30 \mathrm{~g}$ and $2-3$ months of age were acquired from Animal Unit of Biochemical Laboratory, Universitas Airlangga. The mice cage was well ventilated and hygienic. Mice had $12 \pm 1$ day/night schedules. Mice were fed with standard diet and water in ad libitum.

\section{Experimental design}

This study using posttest only controls group design. All the mice were weighed and acclimated for 1 week. During the acclimatization period, all mice were fed with water and a standard diet. After acclimatization period, mice were divided into 5 groups, that consisted of KO1 (normal group), KO2 (Hypercholesterolemic group), KO3 (1st treatment group), $\mathrm{KO} 4$ (2nd treatment group), and $\mathrm{KO} 5$ (3rd treatment group), through simple random sampling technique.

Mice in KO1 were fed with a standard diet and water ad libitum. Mice in $\mathrm{KO} 2, \mathrm{KO} 3, \mathrm{KO} 4$, and $\mathrm{KO} 5$ were fed with high fat diet ad libitum and $1 \mathrm{~mL}$ duck egg yolk through gastric tube each day for 5 weeks to induce hypercholesterolemia state. After 5 weeks, mice in $\mathrm{KO} 3$, $\mathrm{KO} 4$, and $\mathrm{KO} 5$ were given of avocado leaf and seed extract in the combination doses of $10 \mathrm{mg} / \mathrm{kgBW}$ and $250 \mathrm{mg} /$ $\mathrm{kgBW}, 20 \mathrm{mg} / \mathrm{kgBW}$ and $250 \mathrm{mg} / \mathrm{kgBW}, 40 \mathrm{mg} / \mathrm{kgBW}$ and $250 \mathrm{mg} / \mathrm{kgBW}$, respectively. All of the doses were given through an intragastric route to the mice once a day for 4 weeks and continuously fed with high fat diet and duck egg yolk, while mice in KO1 are continuously fed with standard diet and water. The doses used in this study was a new combination made based on several similar previous studies where the extracts were given individually., 4

At the end of the study, all mice fasted for 6 hours, then all mice were anesthetized by ketamine to collect the blood by cardiac puncture technique into $3 \mathrm{~mL}$ syringe.

\section{Biochemical analysis}

Total cholesterol was measured with the CHOD PAP method using analyzer and CHOD PAP kit. LDL and HDL were measured with the direct method using analyzer and its reagent. All measurement was done at Balai Besar Laboratorium Kesehatan Surabaya.

\section{Statistical analysis}

Value of total cholesterol, LDL, and HDL level was presented as the mean \pm standard deviation (SD). The data were analyzed using SPSS ver. 17.0 (IBM Corp.). Distribution of data was analyzed using the Shapiro-Wilk test and homogeneity of variance data was analyzed using lavene test. The comparison between groups was analyzed with independent $t$ test and one-way ANOVA. A $p<0.05$ were considered to be statistically significant.

\section{Results}

After 7 weeks of treatment, level of total cholesterol, LDL, and HDL of the mice in all groups were examined. As shown in table I and figure I, mice in hypercholesterolemia group have shown a significant increase in total cholesterol and HDL level compared with the normal group $(p=0,03 ; p=0,024)$. Its LDL tended to increase but did not show significance increase $(p=0,254)$.

Administration of CALSE in all groups proved a decrease in total cholesterol and LDL level although if it was analyzed statistically, it was not significant $(p=0,420 ; p=0,882)$. Compared to hypercholesterolemia group, administration of CALSE in $\mathrm{KO} 3, \mathrm{KO} 4$, and $\mathrm{KO}$, decreased the level of total cholesterol by $17,2 \%, 4,8 \%$, and $1 \%$, respectively $(\mathrm{F}(746.733,750.500)=0.995 ; \mathrm{p}=0,420)$; level of LDL by $16,5 \%, 14,1 \%$, and $10,6 \%$, respectively ( $\mathrm{F}($ $7.650,34.925)=0.219 ; \mathrm{p}=0,882)$. Administration of CALSE had a different effect on HDL level in $\mathrm{KO} 3$ with $\mathrm{KO} 4$ and KO5. CALSE decreased the level of HDL in KO3 by $8,9 \%$ and increased the level of HDL in KO4 and KO5 by $10 \%$ and 9,2\%, respectively, but it did not show any significant difference compared to hypercholesterolemia group $(\mathrm{F}(223.600,79.900)=2.798 ; \mathrm{p}=0,074)$.

Table 1. Effect of high fat diet, duck egg yolk, and CALSE on lipid profile of mice

\begin{tabular}{|c|c|c|c|c|}
\hline \multirow[t]{2}{*}{ Group } & \multirow{2}{*}{$\begin{array}{l}\text { Sample } \\
\text { (n) }\end{array}$} & \multicolumn{3}{|c|}{ Variable } \\
\hline & & $\begin{array}{c}\text { Total } \\
\text { Cholesterol } \\
(\mathrm{mg} / \mathrm{dl})\end{array}$ & $\begin{array}{c}\text { LDL } \\
(\mathrm{mg} / \mathrm{dl})\end{array}$ & $\begin{array}{c}\text { HDL } \\
(\mathrm{mg} / \mathrm{dl})\end{array}$ \\
\hline KO1 & 5 & $90,4 \pm 8,905$ & $11,2 \pm 4,207$ & $59,4 \pm 7,057$ \\
\hline $\mathrm{KO} 2$ & 5 & $154,6 \pm 25,314$ & $17 \pm 9,67$ & $74,2 \pm 9,628$ \\
\hline KO3 & 5 & $128 \pm 30,83$ & $14,2 \pm 3,834$ & $67,6 \pm 5,857$ \\
\hline $\mathrm{KO} 4$ & 5 & $147,2 \pm 24,954$ & $14,6 \pm 3,847$ & $81,6 \pm 9,29$ \\
\hline KO5 & 5 & $153 \pm 28,071$ & $15,2 \pm 4,087$ & $81 \pm 10,7$ \\
\hline
\end{tabular}




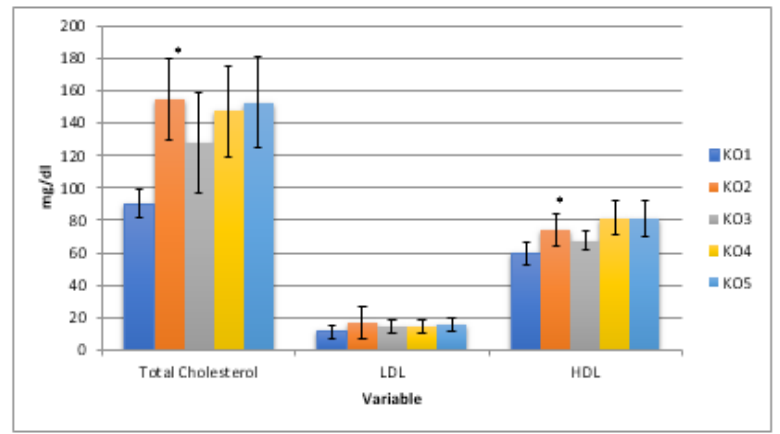

Figure 1. Effect of high fat diet, duck egg yolk, and CALSE on lipid profile of mice. A total of twenty-five mice were randomized into five groups : KO1, normal group with standard diet; KO2, hypercholesterolemic group with high fat diet and duck egg yolk; KO3, 1st treatment group with high fat diet, duck egg yolk, and CALSE (10 mg/kgBW and $250 \mathrm{mg} / \mathrm{kgBW}) ; \mathrm{KO} 4,2$ nd treatment group with high fat diet, duck egg yolk, and CALSE (20 mg/kgBW and $250 \mathrm{mg} / \mathrm{kgBW}$ ); KO5, 3rd treatment group with high fat 325diet, duck egg yolk, and CALSE (40 mg/kgBW and $250 \mathrm{mg} / \mathrm{kgBW}$ ). Values are mean that are presented by vertical bars and standard deviations that presented by a vertical line with cap. *Mean values were significantly difference compared to KO1 $(\mathrm{p}<0,05)$.

\section{Discussion}

Administration of CALSE in $\mathrm{KO} 3, \mathrm{KO} 4$, and $\mathrm{KO} 5$ proved a decrease in total cholesterol and LDL level. These results are in concordance with the previous study in which the administration of avocado seed extract alone caused a decrease in total cholesterol and LDL level, ${ }^{5}$ the same thing happened in the administration of avocado leaf extract alone. ${ }^{4}$ CALSE caused a different effect on HDL in KO3 with $\mathrm{KO} 4$ and $\mathrm{KO} 5$. In $\mathrm{KO} 3$, there was found a decrease of HDL level. On the other hand, in $\mathrm{KO} 4$ and $\mathrm{KO}$, an increase in HDL level was found.

Flavonoid was known to be contained dominantly in avocado leaf extract, while avocado seed extract contained predominantly by saponin. ${ }^{3}$ Both flavonoid and saponin content in CALSE was considered to have a lipid profile lowering effect through each content mechanism including interference in biosynthesis lipid fraction in the liver by flavonoid and disruption of lipid absorption by saponin. Both flavonoid and saponin also work synergistically to increase insulin induced gene $1 / 2$ expression (INSIG1/2). ${ }^{6}$

Different effect on HDL level presumably due to the saponin content in CALSE. As shown in table 1 and figure 1, there was a decrease of HDL level in $\mathrm{KO} 3$ but an increase in HDL level in $\mathrm{KO} 4$ and $\mathrm{KO}$. And there was a weakening of lipid profile lowering the effect of CALSE followed by the increase in CALSE dose. It meant in $\mathrm{KO} 3$, saponin has a stronger lipid profile lowering effect through its disruption to lipid absorption in the intestine and lead to a decrease of HDL level in KO3. Furthermore saponin effect in $\mathrm{KO} 4$ and $\mathrm{KO} 5$ weaker than saponin in $\mathrm{KO} 3$ and lead to an increase in HDL in KO4 and KO5. A decrease of $\mathrm{HDL}$ in $\mathrm{KO} 3$ was in concordance with the previous study which administration of black bean seed coat extract that contained flavonoid and saponin cause a decrease of HDL. ${ }^{6}$

In this study, the lipid lowering effect of CALSE could not cause a significant decrease in total cholesterol and LDL level. This was presumably due to the administration of CALSE dose is not appropriate. As we mentioned before, there was a weakening of lipid profile lowering the effect of CALSE followed by an increase in CALSE dose. It indicated there was a possibility of a stronger lipid profile lowering effect with even lower doses of CALSE. Therefore, CALSE may fulfill the principle of drug combination which by giving a lower dose combination than single administration can achieve efficacy.

High fat diet and duck egg yolk caused a significant increase in total cholesterol and HDL level in mice. It increased the level of LDL too although it was not significant statistically. These results were in concordance with the previous study which administration of high fat diet and duck egg yolk have a correlation with the increased level of cholesterol. ${ }^{10,11}$ High fat diet and duck egg yolk were known to contain a significant amount of unsaturated fatty acid which was known to increase in total cholesterol, LDL, and HDL level ${ }^{12,13}$ through its mechanism in decreasing the LDL receptor in the liver which led to the decrease of chylomicron remnant and LDL clearance in blood. ${ }^{14,15}$ Continuous administration of both high fat diet and duck egg yolk caused the accumulation of fatty acid in the liver that led to an increase in cholesterol synthesis in the liver. ${ }^{15}$ No significant result in LDL level was presumably due to lack of Cholesterylester Transfer Protein enzyme in mice. ${ }^{16}$

The limitation of this study is there was no reference about the right doses of CALSE. Therefore, a further study about CALSE effect on lipid profile needed to be done with more diverse doses.

\section{Conclusion}

Administration of CALSE has the potential to be an anthyperlipidemic agent. Furthermore, CALSE may fulfill the principle as a combination drug because it potentially achieved efficacy with lower doses in the combination form rather than individual form.

\section{Conflict of Interest}

The author stated there is no conflict of interest

\section{References}

1. Mahady GB. Global Harmonization of Herbal Health Claims. The Journal of Nutrition. 2001; 131: 1120S-3S.

2. Yasir M, Das S and Kharya M. The Phytochemical and Pharmacological Profile of Persea Americana Mill. Pharmacognosy Reviews. 2010; 4: 77.

3. Arukwe U, Amadi B, Duru M, et al. Chemical Composition of Persea Americana Leaf, Fruit and Seed. IJRRAS. 2012; 11: 346-9.

4. Kolawole O, Kolawole S, Ayankunle A and Olaniran I. Methanol leaf extract of Persea Americana Protects Rats Against CholesterolInduced Hyperlipidemia. British Journal of Medicine and Medical Research. 2012; 2: 235-42.

5. Pahua-Ramos ME, Ortiz-Moreno A, Chamorro-Cevallos G, et al. Hypolipidemic Effect of Avocado (Persea americana Mill) Seed in a Hypercholesterolemic Mouse Model. Plant Foods for Human Nutrition. 2012; 67: 10-6.

6. Chávez-Santoscoy RA, Gutiérrez-Uribe JA and Serna-Saldívar SO. Effect of flavonoids and Saponins Extracted from Black Bean (Phaseolus vulgaris L.) Seed Coats as Cholesterol Micelle Disruptors. Plant Foods for Human Nutrition. 2013; 68: 416-23.

7. Prince PSM and Kannan N. Protective Effect of Rutin on Lipids, Lipoproteins, Lipid Metabolizing Enzymes and Glycoproteins in 
Streptozotocin Induced Diabetic Rats. Journal of Pharmacy and Pharmacology. 2006; 58: 1373-83.

8. Gnoni G, Paglialonga G and Siculella L. Quercetin Inhibits Fatty Acid and Triacylglycerol Synthesis in Rat Liver Cells. European Journal of Clinical Investigation. 2009; 39: 761-8.

9. Marrelli M, Conforti F, Araniti F and Statti G. Effects of Saponins on Lipid Metabolism: A Review of Potential Health Benefits in the Treatment of Obesity. Molecules. 2016; 21: 1404.

10. Ishihara A, Ito A, Sakai K, Watanabe $S$, Kobayashi $T$ and Okuyama H. Dietary High-Linoleate Safflower Oil Is Not Hypocholesterolemic in Aged Mice after a Long-Term Feeding-Comparison with Lard, Perilla Oil and Fish Oil. Biological and Pharmaceutical Bulletin. 1995; 18: 485-90.

11. Andari F and Rahayuni A. Pengaruh Pemberian Serbuk Biji Labu Kuning (Cucurbita moschata) Terhadap Penurunan Kolestrol Total Tikus Wistarn Hipertkolesteromia. Journal of Nutrition College; Vol 3, No 4 (2014): Oktober 2014. 2014.
12. Mustad VA, Ellsworth JL, Cooper AD, Kris-Etherton PM and Etherton TD. Dietary Linoleic Acid Increases and Palmitic Acid Decreases Hepatic LDL Receptor Protein and mRNA Abundance in Young Pigs. Journal of lipid research. 1996; 37: 2310-23.

13. Siri-Tarino PW, Sun Q, Hu FB and Krauss RM. Saturated Fatty Acids and Risk of Coronary Heart Disease: Modulation by Replacement Nutrients. Current Atherosclerosis Reports. 2010; 12: 384-90.

14. Fernandez ML and West KL. Mechanisms by Which Dietary Fatty Acids Modulate Plasma Lipids. The Journal of Nutrition. 2005; 135: 2075-8.

15. Hall JE. Guyton and Hall Textbook of Medical Physiology. Philadelphia, PA: Saunders Elsevier. 2011; 107.

16. Gordon SM, Li H, Zhu X, Shah AS, Lu LJ and Davidson WS. A Comparison of the Mouse and Human Lipoproteome: Suitability of the Mouse Model for Studies of Human Lipoproteins. Journal of Proteome Research. 2015; 14: 2686-95. 